Available online on 15.05.2021 at http://ujpr.org
Universal Journal of Pharmaceutical Research
An International Peer Reviewed Journal
Open access to Pharmaceutical research

\title{
ANTIVIRAL ACTIVITY OF EXTRACT AND PURIFIED COMPOUND FROM RED MACROALGAE ASPARAGOPSIS TAXIFORMIS AGAINST H5N1 VIRUS Emad A. Shalaby ${ }^{1 *}$, Sanaa M. M. Shanab ${ }^{2} \mathbb{C}$ \\ ${ }^{1}$ Department of Biochemistry, Faculty of Agriculture, Cairo University, 12613 Giza, Egypt. ${ }^{2}$ Department of Botany and Microbiology, Faculty of Science, Cairo University, 12613 Giza, Egypt.
}

\section{ABSTRACT}

Aim and objective: The discovery and development of new natural antiviral compounds which exhibit various antiviral activities are required. The aim of this investigation is to assess the potential use of the red seaweed Asparagopsis taxiformis as a new source of anti $\mathrm{H}_{5} \mathrm{~N}_{1}$ agent.

Methods: The seaweed was collected from Marsa Matrouh, Mediterranean Sea, Egypt during spring season, the effects of successive extracts and the pure compounds from the investigated alga on $\mathrm{H}_{5} \mathrm{~N}_{1}$ virus were performed using plaque reduction assay. In addition, the mechanism of action of promising extract on the virus adsorption and replication was determined. Chromatographic and spectroscopic analyses were used for the identification of chemical structure of active compound(s) isolated from the studied seaweed.

Results: The obtained results showed that petroleum ether and water algal extracts exhibited high antiviral activity (>99.9\%) and the mode of action of extracts was not correlated with virus replication but with its adsorption process. The isolated pure compound was identified as 6-methyl- $\Delta^{22}$-stigmasterol-2, 3 di acetate and its antiviral activity (for $\mathrm{H}_{5} \mathrm{~N}_{1}$ ) was tested. Pure compound showed antiviral activity reached $56 \%$ at $100 \mu \mathrm{g} / \mathrm{ml}$.

Conclusion: The obtained results suggests that crude extracts and isolated active compound from A. taxiformis has the capacity to protect people against pandemic $\mathrm{H}_{5} \mathrm{~N}_{1}$ preventing virus adsorption to the human host cells. Recommendation for testing the extracts and pure compounds from the studied seaweed as potential inhibitor of COVID-19.

Keywords: Antiviral activity, Asparagopsis taxiformis, $\mathrm{H}_{5} \mathrm{~N}_{1}$ virus, mode of action.

Article Info: Received 25 February 2021; Revised 29 March; Accepted 4 May, Available online 15 May 2021

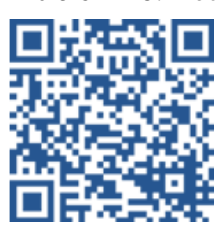

Cite this article-

Shalaby EA, Shanab SMM. Antiviral activity of extract and purified compound from red macroalgae Asparagopsis taxiformis against H5N1 virus. Universal Journal of Pharmaceutical Research 2021; 6(2):14-19.

DOI: https://doi.org/10.22270/ujpr.v6i2.573

Address for Correspondence

Dr. Emad A. Shalaby, Department of Biochemistry, Faculty of Agriculture, Cairo University, 12613 Giza, Egypt; E-mail: dremad2009@yahoo.com

\section{INTRODUCTION}

In general, IAV or Influenza A virus is a healthy threat to the human community. This virus has high ability for infecting various hosts e.g: horse's waterfowl, dogs, cats, humans, and other mammals. $\mathrm{H}_{5} \mathrm{~N}_{1}$ virus induces public health and economic problems because of direct contact with birds and indirect contact with contaminated media transmits the virus to people ${ }^{1}$. New antiviral drugs are needed to nullify the percentage of mortality caused by virus infection. Neuraminidase inhibitors (NALs) drugs were worldwide used in curing the IAV infected people, but its use nowadays were less effective $e^{2,3}$. Therefore, the findings or development of natural anti-influenza virus drugs is recommended. Macroalgal species well known or recognized as ecosystem engineers and/or foundation organisms in different environment or habitats since they convert the simple surfaces into structured environments that support many of living species ${ }^{4}$. Cardozo et al., reported that algal products are essential components in many industries ${ }^{5}$. Algae synthesize many bioactive substances that exhibit different biological activities ${ }^{6}$. In relation to the activity of antiviral and marine seaweed species, the algal species have high ability for producing and providing novel leads against various viruses e,g: $\mathrm{H}_{5} \mathrm{~N}_{1}, \mathrm{H}_{1} \mathrm{~N}_{1}$, hepatitis, HSV etc become less sensitive to the existing drugs as reported by $\mathrm{Vo}$ and $\mathrm{Kim}^{7}$, et al. Thus, Algal species (especially seaweeds or macroalgae) are regarded as a promising source for antiviral drugs. This investigation aimed to assess the effect of successive extracts and pure compound isolated from A. taxiformis 
red macroalga on $\mathrm{H}_{5} \mathrm{~N}_{1}$ virus and identify the mode of action.

\section{MATERIALS AND METHODS}

\section{Solvents}

Pure hexane, petrolium ether, chloroform, ethyl ether, ethyl acetate, methylene chloride, ethanol, methanol, acetone, acetic acid, tween (20 and 40) and DMSO were obtained from Merch (Germany). All solvent were distilled before use.

\section{Collection of alga}

The alga was harvested from El-Garam beach of Marsa Matrouh. The alga belong to Bonnemaisoniaceae (Asparagopsis sp, supra littoral and intertidal zones, $11-13 \mathrm{~cm})$. Algal thalli were washed from sand and debris by sea water then by fresh water. After preparation of herbarium specimens of the alga, the alga was identified as A. taxiformis by the phycologist Prof. Dr. Sanaa M. Shanab, Botany and microbiology Department, Faculty of Science, Cairo University.

Quantitative analysis of alga secondary metabolites Total Glycosides

The total glycosides content in A. taxiformis was extracted and spectrophotometrically determined (as glucose) using the method described by Dubois et al., ${ }^{8}$. Total saponin

Saponins were estimated by the method used by Ebrahimzadeh and Niknam method".

\section{Total Alkaloids}

Alkaloids were determined by the method used by Sabri et al..$^{10}$.

Total organic acids

Plant acids in macroalga were determined using titratable acidity method according to Harborne ${ }^{11}$.

\section{Phenolic compounds}

Total phenolics contents in the studied seaweed were estimated by the method reported by Meda et al., and the standard curve was established using Ferulic acid $^{12}$.

\section{Preparation of algal extracts}

Fifty grams of the seaweed was extracted by successive organic solvent of increasing polarity (from the nonpolar hexane to the highly polar water). All extracts were dried under vacuum using rotary evaporator and weighed according to Rosenthaler ${ }^{13}$.

\section{Antiviral activity}

Antiviral bioassay was prepared according to the method of Silva et al. ${ }^{14}$. A known weight of each seaweed extract was dissolved in one $\mathrm{ml}$ of $10 \%$ DMSO, to give a final concentration of $100 \mu \mathrm{g} / \mu 1$ and served as stock solution. These solutions were sterilized by the addition of a commercial antibiotic antimycotic mixture $(10,000 \mathrm{U}$ Penicillin sodium or 25 $\mu \mathrm{g}$ amphotericin $\mathrm{B}, \quad 10.000 \mu \mathrm{g}$ streptomycin sulphates). Then a sterility test was carried out in nutrient agar.

Cells

MDBK cells: The cell lines of MDBK were obtained and propagated in Virology Laboratory, National Research Center (NRC).

\section{Media and supplements}

Media: The Minimum essential medium and RBMI 1640 medium were prepared from powdered stock and $\mathrm{pH}$ was adjusted to 7.3 with $\mathrm{NaHCO}_{3}$. The prepared media were sterilized by filtration through nitrocellulose membrane filter (pore size of $0.2 \mu \mathrm{m}$ ). Sterility test was carried out on nutrient agar plates.

\section{Supplements}

Firstly a cell dissociation solution $(0.15 \%$ Trypsin, $0.04 \%$ versene mixture) was prepared as follows: Phosphate buffered saline (0.15 M, pH 7.5, PBS) was sterilized by $0.22 \mu \mathrm{m}$ nitrocellulose membranes, then used for washing of cell monolayer sheets and in preparation of cell dissociation solution. The dissociation solution was composed of $1.5 \mathrm{~g}$ of trypsin powder (1:250, Sigma-Aldrich) dissolved in $500 \mathrm{ml}$ PBS and incubated overnight at $4^{\circ} \mathrm{C}$ with stirring. Total $0.04 \%$ Versene solution, Fetal bovine serum (SigmaAldrich) and Antibiotic-antimycotic mixture (10,000 U Penicillin sodium or $25 \mu \mathrm{g}$ amphotericin B, $10.000 \mu \mathrm{g}$ streptomycin sulphates, Sigma-Aldrich) were also prepared. 0.04 gram tetra sodium salt of ethylene diamine tetra acetic acid (EDTA) was dissolved in 500 $\mathrm{ml}$ of 1.5 M PBS ( $\mathrm{pH} 7.5$ ) and mixed with equal volume of trypsin-versene mixture, this solution was adjusted to $\mathrm{pH} 8.4$ by $7.5 \% \mathrm{NaHCO}_{3}$ solutions and sterilized by filtration through $0.22 \mu \mathrm{m}$ nitrocellulose membrane. All the reagents were stored at $-20^{\circ} \mathrm{C}$ until used.

\section{Reference viruses}

Avian virus $\left(\mathbf{H}_{5} \mathbf{N}_{1}\right)$ : The virus was kindly given by Virology Laboratory, NRC. It was propagated and titrated on MDBK cells as indicated by Silva et al. ${ }^{14}$.

Materials for plaque infectivity assays:

Over layer medium was prepared as follows: Double strength concentration of both types of media was prepared and sterilized by filtration. Supplements were added to concentration of $2 \%$ antibiotic-antimycotic. Total $2 \%$ Agarose solution was prepared by cooking 2 $\%$ agarose in deionized water and sterilized by autoclaving. Ten $\%$ formalin in $\mathrm{H}_{2} \mathrm{O}$ was used as fixative solution. Staining solution was made by dissolving $1 \%$ crystal violet in $20 \%$ methanol (w/v) and then filtered through Whatman no. 1 paper.

\section{Plaque infectivity reduction assay}

Anti- $\mathrm{H}_{5} \mathrm{~N}_{1}$ assay

A 6-well plate was cultivated with MDBK culture $\left(10^{5} \mathrm{cell} / \mathrm{ml}\right)$ and incubated for 2 days at $37^{\circ} \mathrm{C}$. The culture of $\mathrm{H}_{5} \mathrm{~N}_{1}$ virus was diluted to give $10^{7} \mathrm{PFU} / \mathrm{ml}$ as final concentrations and mixed with the algal extract and incubated overnight at $4^{\circ} \mathrm{C}$. Growth medium was removed from the multiwell plate and the viruscompound mixture was inoculated $(100 \mu \mathrm{l} /$ well). After $1 \mathrm{~h}$ contact time, the inocula were aspirated on MDBK culture and $3 \mathrm{ml}$ of MEM with $1 \%$ agarose were overlaid the cell sheets. The plates were left to solidity and incubated at $37^{\circ} \mathrm{C}$ until the development of virus plaques. Cell sheets were fixed in $10 \%$ formalin solution for $2 \mathrm{hr}$ and stained with crystal violet solution. Control virus and cells were treated identically without chemical compounds. Virus plaques were counted and the percentage of inhibition was calculated ${ }^{14,15}$. 


\section{Mode of action}

Crude algal extracts were used for monitoring virus inhibition mechanisms through both viral replications ${ }^{15}$ and viral adsorption assays ${ }^{16}$.

\section{Separation of active gradient}

Ten gram of crude petroleum ether extract was analysed using GL column packed with VLC silica gel H. Elution was performed by hexane, chloroform and their combinations. Fractions were separately collected, evaporated then redisolved in $5 \mathrm{ml}$ ethanol and used by TLC chromatogram (elution system was ethyl acetate, $97: 3 \mathrm{v} / \mathrm{v}$ ). Isolated spots were visualized using UV light at 365 and $245 \mathrm{~nm}$ then colored by anizaldehyde reagent. Fraction No 10 produce the potent pure compound, which was further identified using chromatographic and spectroscopic analyses as LC/MS, UV-Vis spectrophotometer, FTIR, NMR, $\mathrm{CHN}$ analyses.

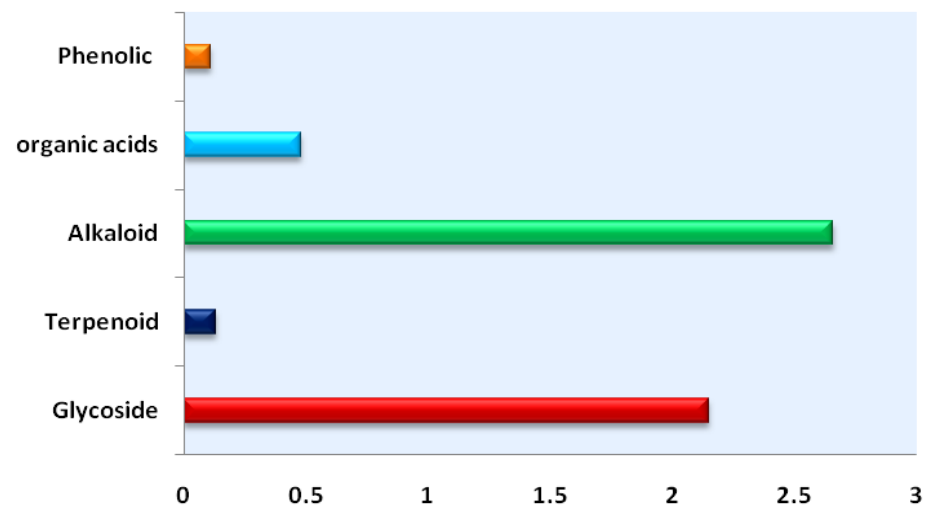

Figure 1: Secondary metabolites content (g/100g d.w) of Asp sp marine macroalgae.

\section{RESULTS AND DISCUSSION}

\section{Secondary metabolites}

Different algal phytochemical contents were illustrated in Figure 1. This result revealed that the A. taxiformis extraction contained the high amount from secondary metabolites as alkaloids followed in descending order by glycosides, plant acids, terpenoids and phenolic compounds, which were $2.66,2.15,0.48,0.13$ and $0.11 \%$, respectively.

\section{Antiviral activity}

The antiviral activity of successive Asparagopsis algal extracts was evaluated against avian virus $\left(\mathrm{H}_{5} \mathrm{~N}_{1}\right)$ virus which used as a model of RNA virus. Table 1 and Figure 2 showed the antiviral activity of different extracts against $\mathrm{H}_{5} \mathrm{~N}_{1}$ by using plaque reduction assay. The obtained results showed that the treatment of H5N1 with different extracts at concentration 20 and $40 \mu \mathrm{g} / \mathrm{ml}$ significantly inhibited $\%$ of $\mathrm{H}_{5} \mathrm{~N}_{1}$ virus (ranged $0.0-100 \%$ ). These means that successive extracts of alga extract exhibited remarkable antiviral activity. Also, the obtained data revealed that the extracts affected viral inhibition in a dose and chemical composition dependent manner (Table 1). Results illustrated that the activity was variable between the extracts according to the polarity of these extracts. In which the maximum inhibition (virus reduction) was occurred in the following extracts: pet ether and water extracts by $100 \%$ ethyl acetate, by $55.5 \%$ at $40 \mu \mathrm{g} / \mathrm{ml}$. These results were in agreement with those reported by Bouhlal et al., ${ }^{17}$ who illustrated that aqueous extracts of different red seaweeds (including A. armata showed antiviral replication activity against Herpes simplex virus type 1 with $\mathrm{EC}_{50}$ range from 2.5 to $75.9 \mu \mathrm{g} / \mathrm{ml}$.

Different extracts of air-dried Ulva lactuca (methanol, ethanol, chloroform, ethyl acetate and diethyl ether) were tested for biological activity and analysed by
TLC. A complex of 6 components was tested for antiviral activity of influenza virus (H1N1). An inhibitory effect was recorded on both viral reproduction and infectious capacity ${ }^{18}$. Spirulina maxima showed an antiviral activity against herpes simplex virus type 2 as reported by Hernandez-Corona et al. ${ }^{19}$, who mentioned that methanol-water extract $(3: 1)$ have the greatest activity which may be due to the polar substances in the extract. It was suggested that the negatively charged sulfated polysaccharides interacted with positively charged cell surface of the virus so preventing its penetration to the host cell ${ }^{20}$.

Table 1: Inhibitory activity of algal extracts by plaque infectivity count assay against H5N1.

\begin{tabular}{lcc}
\hline Treatments & $\begin{array}{c}\text { Conc. } \\
(\boldsymbol{\mu g} / \mathbf{m l})\end{array}$ & $\begin{array}{c}\text { Reduction } \\
\boldsymbol{\%}\end{array}$ \\
\hline Hexane & 20 & 50 \\
& 40 & 57 \\
\hline Petroleum & 20 & 73 \\
ether & 40 & $>99.9$ \\
\hline Ethyl acetate & 20 & 46 \\
Methylene & 40 & 55 \\
chloride : & 20 & 0 \\
Methanol & 40 & 15 \\
$(1: 1$, v/v $)$ & & \\
\hline \multirow{2}{*}{ Water } & 20 & $>99.9$ \\
& 40 & $>99.9$ \\
\hline
\end{tabular}

Mechanism of algal extracts as antiviral activity The effect of algal extract on virus replication In these experiments the activities of algal extracts against $\mathrm{H}_{5} \mathrm{~N}_{1}$ and the clinical strain were evaluated by the plaque reduction assay. No effect of algal extract on viral replication was recorded but it affects virus $\mathrm{H}_{5} \mathrm{~N}_{1}$ adsorption on the host cell (Figure 3 and Figure 4). 


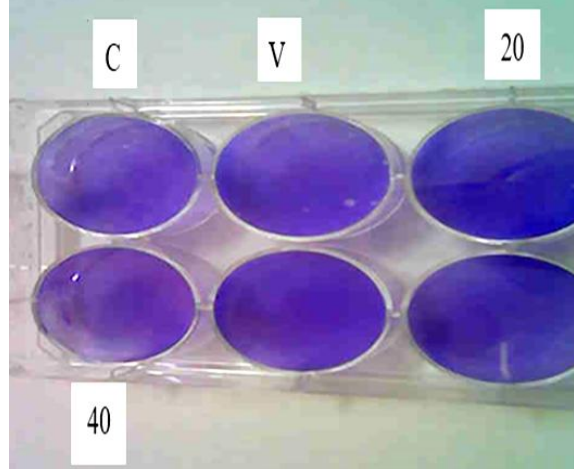

Figure 2: Effect of algal extract against H5N1 virus.

$\mathrm{C}=$ Cell control; $\mathrm{V}=$ Virus control; 20 $40=$ concentration $/ \mu \mathrm{g}$ of algal extract used in treating each well. Color wells=no viral growth; dotted wells=obvious virus growth.

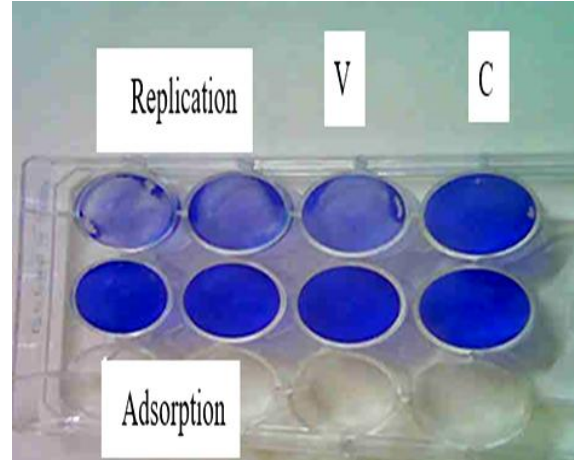

Figure 4: In vitro mode of action of Algal extract on H5N1 infection.

$\mathrm{C}=$ Cell control; $\mathrm{V}=$ Virus control; Color wells=no viral growth; dotted wells=obvious virus growth

The effect of algal extract on virus adsorption

The inhibitory effect of algal extracts on virus adsorption to host cell was measured by monitoring the attachment of infectious $\mathrm{H}_{5} \mathrm{~N}_{1}$ virions on to host cells in the presence of extracts. As shown in Figure 3 and Figure 4, extracts inhibited the cell-associated infectivity by $100 \%$ of the control levels. These results go parallel with those reported by Carlucci et al., who showed that the sulphated galactan in the red algal extract inhibited the adsorption of herpes simplex virus (HSV-1 and HSV-2). In addition, the cyanovirin-N (CV-N) from the cyanobacterium Nostoc $s p$ inhibited HIV-2 through the interaction with glycoprotein (gp120) of the viral envelope ${ }^{21}$.

Isolation and identification of the bioactive compounds

During the isolation of the active compounds from $A$. taxiformis alga, the non-polar extract (petroleum ether extract) was more effective than other organic solvent extracts as antiviral activity as shown in Table 1. Further fractionation of petroleum ether extract yielded pure compound; the obtained compounds were tested for antiviral activity against $\mathrm{H}_{5} \mathrm{~N}_{1}$ virus. The result showed that this pure compound had antiviral activity by $56 \%$ at $100 \mu \mathrm{g} / \mathrm{ml}$ as shown in Figure 5 . These results may be attributed to the presence of various active groups in the isolated compound (6-methyl- $\Delta 22$ -

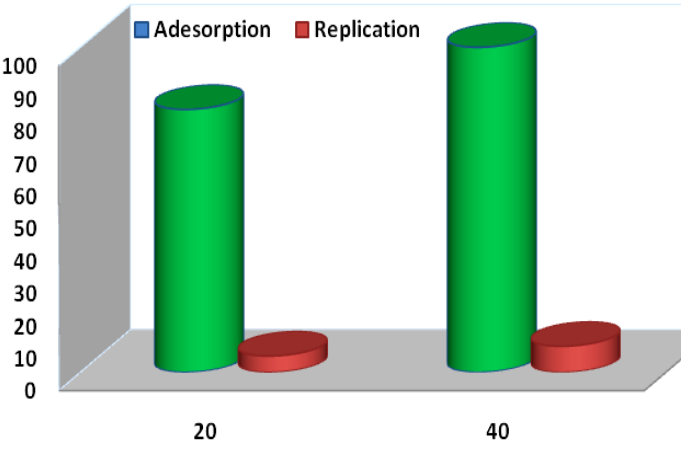

Figure 3: In vitro mode of action of ASP algal extract on H5N1 infection.

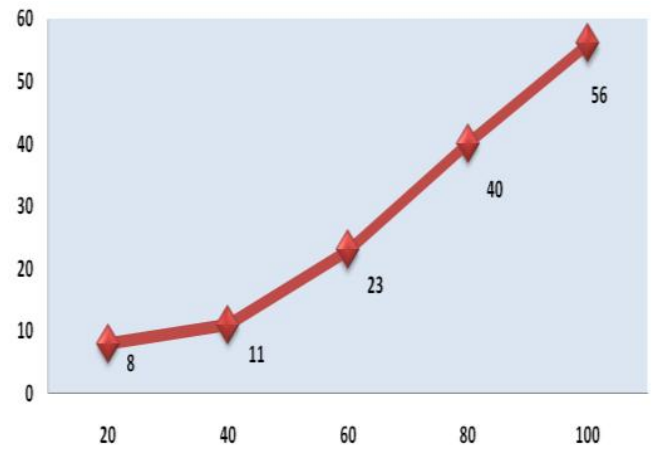

Figure 5: The Antiviral activity of different concentration of Asparagopsis sp pure compounds against $\mathrm{H5N} 1$ virus.

stigmasterol-2, 3 di acetate) such as Acetate group, double bonds in the chemical structure of this compound and its conformational structure that increase from the ability of this compound to react and bind with virus protein and prevent its adsorption into specific receptor.

The chemical structure of active ingredients isolated from A. taxiformis

Figure 6 presented the suggested chemical structure configuration of the active constituents of the algal petroleum ether. The proposed configuration satisfies and complies with the analytical identification characteristics shown by the CHN Elemental Analyzer, UV, IR, spectroscopic and chromatographic analyses used.

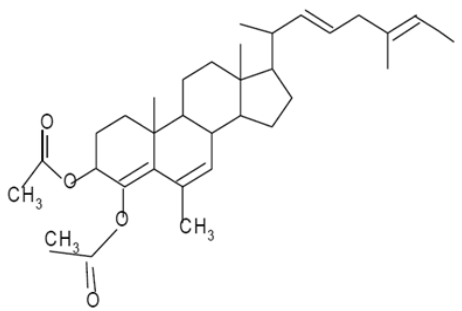

Figure 6: Suggested chemical structure of active ingredients (6- Methyl $\Delta^{22}$ stigmasterol- 1, 3 di acetate) separated from macroalgae (A. taxiformis) 

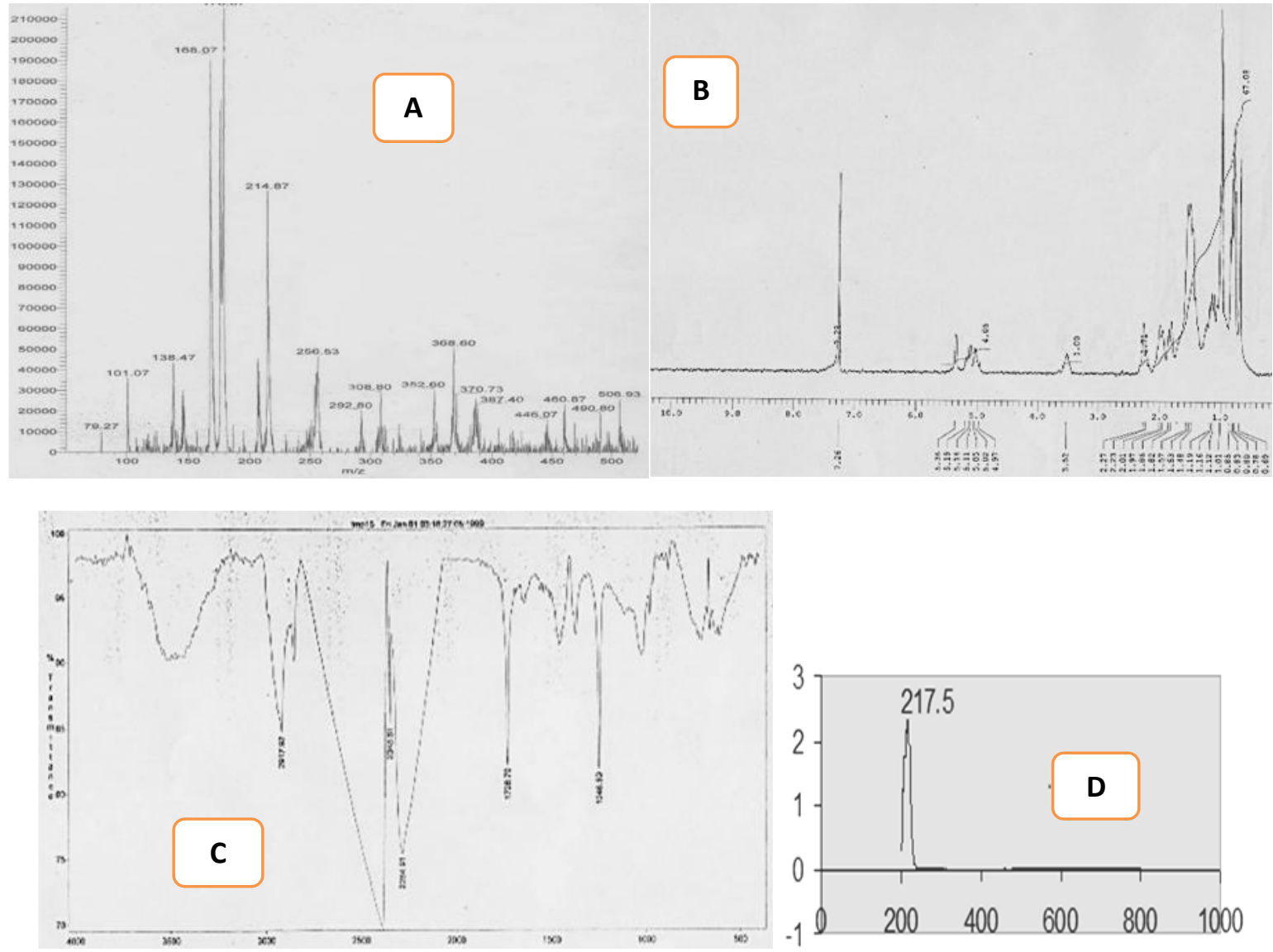

Figure 7: The spectroscopic analysis of isolated compound from Asp. A: Positive ESI/MS spectrum of compound; B: 1HNMR spectrum; C: IR spectrum and D: UV spectrum.

Sub-fraction with TLC Rf value of 0.13 , was analyzed by HPLC, LC-MS and GC-MS. The results revealed the presence of 3 compounds of which, one major constituent was found as main compounds (>96\%). As can be seen in the IR spectra (Fig.7), the intense bands in region between 2935 and 2850 and at $1660 \mathrm{~cm}-1$ was shows due to presence of $-\mathrm{CH}_{2}$ and $-\mathrm{CH}_{3}$ groups and double bond. The $-\mathrm{OH}$ group of steroid has and intense band in region between 3000 and $3360 \mathrm{~cm}-1$. The compound has an intense band at $1725 \mathrm{~cm}-1$, characteristic of the carbonyl group, and the $\mathrm{C}-\mathrm{O}$ stretching band at $1265 \mathrm{~cm}-1$ and a second IR C-O band at 1032 was found. The band at 1032 is special for the cholestryl acetate ${ }^{22}$. Also, IR spectrum showed band at 1626 and $823 \mathrm{~cm}-1$ ( $\Delta$ ethylidine sterol). The mass spectrum of compound exhibited the molecular ion peak at $\mathrm{m} / \mathrm{z} 506.8$ corresponding to molecular formula $\mathrm{C}_{33} \mathrm{H}_{47} \mathrm{O}_{4}$. The mass spectrum showed the intense ion peak at $\mathrm{m} / \mathrm{z} 490(\mathrm{M}-\mathrm{OH})+, 460(\mathrm{M}+-\mathrm{OH}-$ $\left.\mathrm{CH}_{3} \mathrm{CH}_{2}\right), \quad 447$ (M+-OH-CH $\left.\mathrm{CHOO}_{3} \mathrm{CO}\right), 387$ (M+$\left.\mathrm{CH}_{3} \mathrm{COO}-\right)$. The other intense peaks appeared at $\mathrm{m} / \mathrm{z}$ $354\left(\mathrm{M}-\mathrm{H}_{2} \mathrm{OC}_{3} \mathrm{H}_{7}\right)+, 294\left(\mathrm{M}-\mathrm{H}_{2} \mathrm{O}-\mathrm{C}_{7} \mathrm{H}_{15}\right)+, 245(\mathrm{M}-$ side chain $\left.\left(\mathrm{C}_{10} \mathrm{H}_{21}\right)\right)+, 206\left(\mathrm{M}-\mathrm{H}_{2} \mathrm{O}\right.$-side chain $\left(\mathrm{C}_{13}\right.$ $\left.\left.\mathrm{H}_{25}\right)\right)+, 168\left(\mathrm{C}_{12} \mathrm{H}_{24}\right)+, 138\left(\mathrm{C}_{12} \mathrm{H}_{18}\right), 107\left(\mathrm{C}_{8} \mathrm{H}_{11}\right)$ and $79\left(\mathrm{C}_{6} \mathrm{H}_{7}\right)$. This showed the presence of steroidal skeleton. According to the obtained data the chemical structure of isolated compound was elucidated as 6methyl- $\Delta 22$-stigmasterol-2, 3 di acetate.

\section{CONCLUSION}

The red alga A. taxiformis was evaluated in this study as a new source of antivirus against $\mathrm{H}_{5} \mathrm{~N}_{1}$. Successive extractions with organic solvents of increasing polarities were performed [hexane, petroleum ether, ethyl acetate, methylene chloride: methanol $(1: 1 \mathrm{v} / \mathrm{v})$, water] using concentrations 20 and $40 \mu \mathrm{g} / \mathrm{ml}$. Petroleum ether and water extracts showed the highest antiviral activity (>99.9\%) using plaque reduction assay. Fractionation of the nonpolar petroleum ether extract yielded a pure active compound of steroidal skeleton with antiviral activity against $\mathrm{H}_{5} \mathrm{~N}_{1}$. It may be due to the presence of different active groups as acetate group and double bonds in the chemical configuration of the compound (6-methyl-422-stigmasterol-2,3di acetate) which increase the ability of the compound to react and bind with the virus protein envelope and so prevent its adsorption on specific receptors. The mode of action of algal extract and the active compound was shown to be through inhibition of virus adsorption and not its replication.

\section{AUTHOR'S CONTRIBUTION}

The study was designed and conducted in collaboration of all the authors. They declare that they have written and approved the present manuscript. 


\section{ACKNOWLEDGEMENTS}

The authors extend their thanks and appreciation to the Department of Biochemistry, Faculty of Agriculture, Cairo University, 12613 Giza, Egypt to provide the reagents and place for laboratory tests.

\section{CONFLICT OF INTEREST}

No conflict of interest associated with this work.

\section{REFERENCES}

1. Lu Y, Landreth S, Liu G, Brownlie R, Gaba A, Hurk S, Gerdts V, Zhou Y. Innate immune modulator containing adjuvant formulated HA based vaccine protects mice from lethal infection of highly pathogenic avian influenza H5N1 virus. Vaccine 38; 2387-2395. https://doi.org/10.1016/j.vaccine.2020.01.051

2. Tamura D, Sugaya N, Ozawa M, et al. Frequency of drugresistant viruses and virus shedding in pediatric influenza patients treated with neuraminidase inhibitors. Clin Infect Dis 2011; 52:432-437. https://doi.org/10.1093/cid/ciq183

3. Takashita E, Fujisaki S, Kishida N, et al. Characterization of neuraminidase inhibitor-resistant influenza $A\left(\mathrm{H}_{1} \mathrm{~N}_{1}\right)$ pdm09 viruses isolated in four seasons during pandemic and post-pandemic periods in Japan. Influenza Other Respir. Viruses 2013; 7:1390-1399. https://doi.org/10.1111/irv.12132

4. Thomsen MS, Wernberg T, Staehr PA, Schiel D. Ecological interactions between marine plants and alien species E. Ólafsson (Ed.), Marine macrophytes as foundation species, CRC Press, Taylor and Francis Group, Boca Raton (USA) ;2017:277. https://doi.org/10.4324/9781315370781-11

5. Cardozo KHM, Guaratini T, Barros MP, et al. Metabolities from algae with economical impact. Comparative Biochem Physiol 2006; 146: (1-2): 60-78. https://doi.org/10.1016/j.cbpc.2006.05.007

6. Plaza M, Cifuentes A, Iba'ñez E. In the search of new functional food ingredients from algae. Food Sci Tech 2008; 19:31-39.https://doi.org/10.1016/j.tifs.2007.07.012

7. Vo TS, Kim SK. Potential anti-HIV agents from marine resources: An overview. Mar Drugs 2010; 8, 2871-2892. https://doi.org/10.3390/md8122871

8. DuBois M, Gilles KA, Hamilton JK, Rebers PA, Smith F. Colorimetric method for determination of sugars and related substances. Anal. Chem 1956; 28, 3:350-356. https://doi.org/10.1021/ac60111a017

9. Ebrahimzadeh H, Niknam V. A revised spectrophotometric method for determination of triterpenoid saponin. Indian Drugs 1998; 35: 379-381.
10. Sabri NN, El-Masry S, Khafagy SM. Phytochemical investigation of Hyoscyamus desertorum. Planta Medica 1973; 23: 49. https://doi.org/10.1055/s-0028-1099408

11. Harborne JB. Phytochemical Methods. Chapman and Hall Ltd., London 1973; 49-188.

12. Meda A, Lamien CE, Romito M, Millogo J, Nacoulma OG. G. Determination of the total phenolic, flavonoid and praline contents in Burkina Fasan honey, as well as their radical scavenging activity. Food Chem 2005; 91: 571-577. https://doi.org/10.1016/j.foodchem.2004.10.006

13. Rossenthaler L. The chemical investigation of plants. Translated into English by Sudhamoy Ghosh from the Third German edition. Bell and Sons. Ltd London 1930.

14. Silva O, Barbose S, Diniz A, Valdeira M, Gomes E. Plant extracts antiviral activity against Herpes Simplex virus type 1 and African Swine Fever virus. Int J Pharm 1997; 35: 1216. https://doi.org/10.1076/phbi.35.1.12.13264

15. Amoros M, Lurton E, Boustie J, Girre L. Comparison of the anti-herpes simplex virus activities of propolis and 3methyl-But-2-Enyl cafferate. J Nat Prod 1994 57(5):644647. https://doi.org/10.1021/np50107a013

16. Zhang J, Zhan B, Yao X, Gao Y, Shong J. Antiviral activity of tannin from the pericarp of Punica granatum L. against genital Herpes virus in vitro. Zhongguo Zhong Yao Za Zhi 1995; 20(9):556-8, 576. PMID: 8679095

17. Bouhlal R, Riadi H, Bourgougnon N. Antiviral activity of the extracts of Rhodophyceae from Morocco. African J Biotech 2010; 9: 7968-7975. https://doi.org/10.5897/AJB09.2023

18. Ivanova V, Rouseva R, Kolarova M, et al. Isolation of a polysaccharide with antiviral effect from Ulva lactuca. Prep Biochem 1991; 24: 83-97. https://doi.org/10.1080/10826069408010084

19. Hernández-Corona A, Nieves I, Meckes M, Chamorro G, Barron BL. Antiviral activity of Spirulina maxima against herpes simplex virus type 2. Antiviral Res 2002; 56(3):279-85.https://doi.org/10.1016/s0166-3542(02)00132-8

20. Ehresmann D, Deig EF, Hatch MT. Antiviral properties of algal polysaccharides and related compounds. In: "Marine Algae in Pharmaceutical Science" (Eds. Hoppe, H.; Levring, T. and Tanaka, Y.). Walter de Gruyter, Berline. New York 1979; 293-302.

21. Carlucci MJ, Pujol CA, Ciancia M, et al. Antiherpetic and anticoagulant properties of carrageenans from the red seaweed Gigartina skottsbergii and their cyclized derivatives: correlation between structure and biological activity. Int J Biol Macro 1997; 20:97-105. https://doi.org/10.1016/s0141-8130(96)01145-2

22. Griffiths WJ, Shackleton C, Sjo“vall J. Steroid analysis. In: Caprioli, R. (Ed.), Encyclopedia of Mass Spectrometry 2005; vol. 3. Elsevier, Oxford. 